\title{
Practice and Reflection on the implementation of water administrative license in Hubei Province
}

\author{
Ke Guannian \\ Wuhan University of Technology, Wuhan 430070, China \\ 987544472@qq.com \\ Ke Guannian
}

Keywords: Water administrative licensing, Social benefits, Water resource, Problems and suggestions.

\begin{abstract}
In accordance with the laws and regulations such as The People's Republic of China water law and The implementation methods of the "People's Republic of China water law" in Hubei Province, Hubei has set up Water administrative license that directly relate to public safety, ecological environment protection, and direct relation to personal health and life and property safety, and the projects that need to be approved according to the legal conditions. administrative licensing. Based on the practice of water administrative examination and approval in Hubei Province, this paper analyzes and studies the social benefits and existing problems of water administrative license, and puts forward some suggestions for improving the work of water administrative license in the next step.
\end{abstract}

\section{Introduction}

The purpose of water administrative license is to ensure and supervise the effective implementation of water administrative management, to ensure the rational use of water resources and to effectively protect the ecological environment of water. In recent years, under the background of further transformation of government functions and improving administrative efficiency, the management of water administrative licensing has been gradually standardized. At the same time, water administration departments have carried out water conservancy reform in depth, the approval items of water administrative license have been greatly reduced, administrative examination and approval authority have been decentralized, and the setting of water administrative license has also changed.

In recent years, with the continuous clearing up of administrative examination and approval intermediary services by the State Council, the establishment of provincial water administrative license in Hubei province has also undergone a series of changes, including: in 2015, the State Council issued The decision on the first batch of 89 departments of State Council administrative examination and approval intermediary service (No. 58 [2015]), and Hubei province correspondingly to the provincial administrative approval items, and the water administrative licensing project was reduced from 13 items in 2013 to 9. In 2016, the State Council issued The decision on the second batch of cleaning and regulating 192 items of administrative examination and approval of the Department of the State Council (No. 11),In Hubei, the provincial administrative licensing projects were once again cleaned and adjusted, and 7 items were retained, respectively:The examination and approval of the construction project water resources demonstration report and the permission for water intake; the approval to construct or expand the sewage outlet on the rivers and lakes, ; the qualification of the quality inspection department of the water conservancy projects (Grade B); the approval of the water and soil conservation scheme and the acceptance of the facilities; the examination and approval of the flood impact assessment; the river sand mining license; and the preliminary design and approval of the water conservancy infrastructure construction project. 


\section{The social benefit of the water administrative license of Hubei Province}

The implementation of water administrative license maintains public interests and social order, maintains national security and public safety, protects the safety of life and property of citizens, and helps to promote the coordinated development of the local economy, society and the ecological environment.

Through setting provincial water administrative license, the Water Conservancy Bureau of Hubei province has effectively strengthened the management and protection of water resources, which is conducive to the promotion of water resources conservation and rational exploitation and utilization.It makes good social benefits, the main manifestations are:

First, through the implementation of this kind of administrative license, it is beneficial to the scientific management of water resources, to avoid unreasonable use of water, and to promote the conservation and rational exploitation and utilization of water resources.

Second, promote the optimal allocation of water resources. The control of the total amount of water intake is based on the approved plan or the signed agreement, and uses the means of total amount control and quota management to ensure the sustainable development of the economy and society in all regions.

Third, promote the economical use of water resources. Through the demonstration of water resources for water related construction projects, the utilization efficiency of water resources is improved, and the limited water resources have been rationally and efficiently utilized

Fourth, avoid the occurrence of water disputes. According to the analysis of the potential influence of other local water users, the influence degree of water use can be fully grasps, and the construction owners and the third parties are required to sign the agreement to avoid the water disputes between the regions and the water users.

Fifth, the system of water intake permits the significant control of the discharge of sewage. And, reducing the discharge of pollutants into the river has played a vital role in maintaining the natural ecosystems, such as land, forest, grassland and desert, which are affected by it.

\section{The main problems existing in the implementation of water administration license in Hubei province.}

With the implementation of the development strategy of the economic belt along the river, the economy of Hubei has developed rapidly. The problems of water ecological environment destruction and the safety of flood control are becoming more and more prominent. It poses a greater challenge to ensure the safety of people's lives and property when the economy is developing. It is necessary to strengthen and improve the water administrative licensing system by listening to the suggestions of experts, and discovering the possible problems in the implementation of the construction project.

\subsection{Problems in the examination and approval}

(1) the basis of examination and approval is more complex. Water administrative licensing involves more legal departments. Its sources include laws, administrative regulations, local regulations, departmental rules and regulations, and local government regulations. Taking water licensing as an example, there is a lack of coordination between policy and law, resulting in unscientific examination and approval and inconsistency in supervision.

(2)partial approval documents are not standardized. First, part of the approval is convergence and lacks pertinence. In the project of water and soil conservation and the entry into the river discharge port, the approval and reply of the water administrative department are similar, and it does not reflect the difference and lack of pertinence of each project. Two, part of the annotation is incomplete. The three is that partial approval of the measurement unit is not unified. 
(3)individual processes are not clear enough. For example, "water resources demonstration management measures for construction projects" only stipulates that water resources argumentation should be carried out before project feasibility report. In actual operation, many projects begin to demonstrate the water resources when only the local development and Reform Commission is approved. The depth of the demonstration is often not enough. It is difficult to achieve the effect of the demonstration.

\subsection{Problems in the construction of water administrative licensing projects}

(1) part of the construction projects failed to strictly follow the industry standards and regulations, for example, there is a phenomenon of inconsistent project construction and approval plan.

(2) some construction projects are not strict in construction management, and inadequate protection measures in the process of construction. After construction, the waste was not completely removed, and the damage to tree vegetation was not recovered in time.

(3) there is no emergency plan and emergency treatment mechanism in some construction projects. The emergency plan for waste water disposal in the condition of accident needs to be strengthened. In the project of flood impact assessment, some projects have not taken prevention and cure measures after the completion of the construction.

\subsection{Problems in the supervision of water administrative licensing projects}

(1) the effect of linkage supervision is not obvious. In the supervision and inspection of water intake projects, there is a lack of communication and cooperation between river basin management agencies and local water level administrative departments. In the approval projects of sewage outlets, there is a coordination between water conservancy departments and environmental protection departments.

(2) partial project supervision is weak. The first is the lack of self supervision in the construction of water administrative licensing project, which is ineffective in monitoring the construction and subsequent construction of the project. Two, the local river management departments failed to fulfill their regulatory responsibilities.

\section{Suggestions on improving the water administrative license of Hubei Province}

\subsection{Further optimize the approval process}

In the process of project approval, the competent authorities should strengthen the scientific review of project declaration documents, and do not permit the project that lack of scientific demonstration In terms of examination and approval procedures, the competent authorities should further optimize the implementation procedures, further clarify the approval process, and clarify the responsibility of examination. The reply of water administrative license should further improve the pertinence, and give clear suggestions on the project category and the actual situation of the project, so as to avoid the uniformity of the contents of the reply.

\subsection{Strengthening the supervision and management of water administrative licensing projects}

The government should standardize the management responsibilities of water administrative licensing, and promote the institutionalization of supervision and inspection. The one is to further clarify the relevant departments responsible for supervision and management. The two is to define and coordinate the authority of basin administration and regional administration, and promote the experience of comprehensive law enforcement supervision and inspection in Yichang. The three is to innovate the way of supervision, make comprehensive use of written examination, sampling survey, on-site supervision, assault inspection, and other forms.The four is to strengthen the professionalism of the water administrative licensing supervision team and improve the Licensee's self supervision and self-management ability. 


\subsection{Establish a long-term regulatory linkage mechanism in key areas}

Through the supervision and inspection by the water administration department, we find that there are relatively many illegal activities in the river sand mining project. With the illegal sand mining into the criminal law, it is suggested that the water administrative departments at all levels should strengthen the connection with the judicial departments, such as the Public Security Bureau, the procuratorate and the court, according to the high judicial interpretations, and conduct the crimes and investigate the criminal responsibility. The water administrative departments must establish a long-term linkage mechanism to enhance the effectiveness of law enforcement and enhance the level of supervision.

\section{Acknowledgement}

Thanks my tutor,Professor Li Mu,for valuable suggestions. Thanks my seniors for their patient help and advice. This paper is supported by the project of Evaluation on the implementation of water administration license of Hubei Provincial Water Resources Department.

\section{References}

[1] Zhu Qiande and Chen Jing, The current situation and suggestions for the implementation of water licensing system in China [J]. People's Yangtze River, 2015,46 (11): 1-5.

[2] Xu Jimin, the State Council set up the practice of administrative licensing. [J]. Administrative law research, 2015 (01): 58-65

[3] Hu Jingpeng and He Ping, Problems in water resources argumentation, [J]. Groundwater , 2010,32 (02): 136-137.

[4] Shi qiuju and Changhong, Several views on Water Resources Argumentation for construction projects [J]. Water science and technology and economy, 2008 (02): 109-110.

[5] [1] Chen Shiyin, On the legal nature of water administration license [J]. Journal of Tianshui Administration College, 2010 (02): 107-110.

[6] [2] Zhang Xiaojun, Analysis of environmental administrative licensing [J]. Environment and sustainable development, 2008 (03): 29-31.

[7] [3]. Jiang bixin, On the nature of administrative license, [J]. Research on administrative law, 2004 (02): 1-5.

[8] [4] Pei Liping. On the necessity of state ownership of water resources [J]. Chinese law, 2003 (05): 103-111. 